\title{
多角バレルスパッタリング法を用いた新しい表面修飾技術
}

\author{
阿 部 孝 之 ${ }^{\mathrm{a}}$, 井上 光 浩 $^{\mathrm{a}}$ \\ a 富山大学 水素同位体科学研究センター（９ 930-855＼cjkstart富山県富山市五福 3190)

\section{Novel Surface Modification Process by the Polygonal Barrel-Sputtering Method}

Takayuki $\mathrm{ABE}^{\mathrm{a}}$ and Mitsuhiro INOUE

${ }^{a}$ Hydrogen Isotope Research Center, University of Toyama(3190, Gofuku, Toyama-shi, Toyama 930-8555)

Keywords : Polygonal Barrel-Sputtering Method, Dry Process, Surface Modification, Zero-, One-, Three-Dimensional Materials, Functional Materials

\section{1.はじめに}

めつき技術による表面修飾は, 装飾, 耐腐食性・耐摩耗性 向上,さらには新機能・特性付与などを目的とした幅広い分 野で用いられている。しかし，一般に「めっき」工程では酸, アルカリや，有害金属(例えば 6 価クロム, カドミウム, や鉛), シアン化合物などの劇毒物, さらにはトリクロロエチレンに 代表される発がん性物質を大量に使用している。これら有害 物質を含む排液は, 環境負荷の低減や公害防止の観点から安 全に処理する必要がある ${ }^{1)}$ 。我が国では，水質污濁防止法の 改正(平成元年)により，めっき事業者は日常的にその排液を 管理, 処理することが義務付けられている。また, 平成 15 年 に施行された土壤污染対策法や種々の都道府県条例により, 設備の更新・撤去時, 事業の停止時において, 土壤污染調査 や土䁃改良が求められている。その他にも, 大気污染防止法, 悪臭防止法などの法令・条例などがあり，もはや国内におい ては, めっき事業の拡大や新規参入が非常に困難な状況になっ ている。

世界的に見ても, 環境問題の先進国である欧州では, 電気・ 電子機器の廃棄物指令 (WEEE) や電気・電子機器部品に含ま れる特定有害物質使用制限指令 $(\mathrm{RoHS})$ により，鉛や 6 価ク ロムなどの使用が制限されている。また， 2007 年に REACH 規則が施行され，有害物質の使用制限が強化されている。一 方, 成長著しい中国では, 従来めっき産業が環境污染源の一 つとなっていた。そのため, 最近欧州の環境規制に準じた中 国版 RoHS が施行され，今後もさらなる規制強化が予想され る。すでに中国の一部地域では日本より厳しい排水基準を設 けているところもある。すなわち, 海外においてもめっき事 業には厳しい目が向けられており, 経済性や生産性よりも環 境への配慮を重視せざるを得ない状況になりつつある。

このような中，めっき事業においても有害物質を使用しない 代替技術が数多く研究されている ${ }^{2)}$ 。しかし，これらの技術は コストなどの問題から未だ普及していない。これに対し，有害 物質を使用せず，排液処理も不要なドライプロセスによる表面 修飾法は, ウエットプロセスの代表的なめっき法の代替技術と
して非常に魅力的である。スパッタリング法 ${ }^{3)}$ は代表的なドラ イプロセスの一つであり, 以前から平板材料(コンパクトディ スクなど)の表面修飾などに使用されてきた。しかし，スパッ タリング法は本質的に高い指向性を有するため, 疑似 2 次元的 な平板材料の修飾技術としては優れているが，3 次元形態を持 つ材料(例えば, ボルト・ナット)や微粒子 (0 次元形態), ナノ チューブ(1 次元形態)材料の表面修飾法としては不向きであっ た。

最近著者らは，スパッタリング技術を基にした新たな材料 表面修飾法として「多角バレルスパッタリング法」を開発し

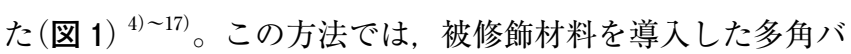
レルを回転, あるいは振り子動作させながらスパッタリング することで(図 1 参照), 材料は擋拌され, 多くの複雑な形状 を有する材料の均一な表面修飾が可能となる。ここでは, 多 角バレルスパッタリング法による表面修飾の一例と本法の応 用例(機能性材料)を幾つか紹介する。
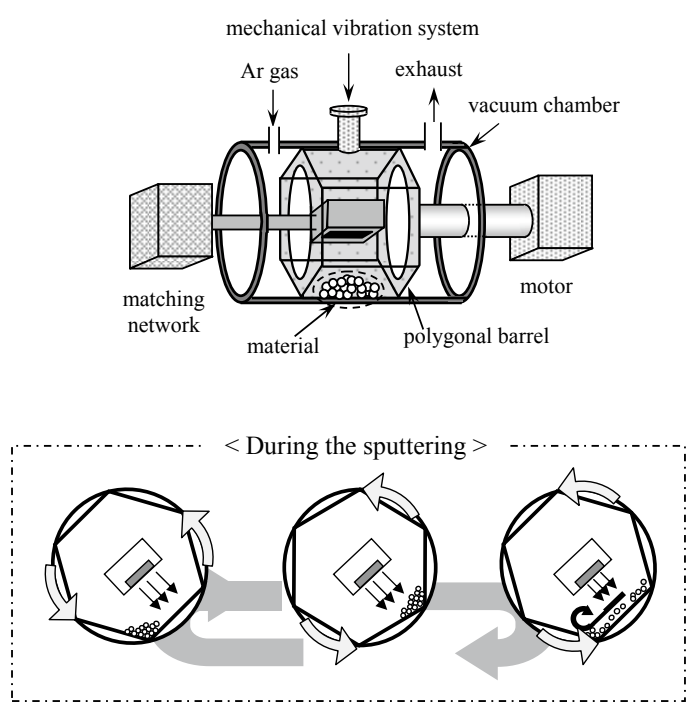

図1 多角バレルスパッタリング装置の概略図 


\section{2. 微粒子 (0 次元) 材料の表面修飾}

\section{1 高分子(ポリメタクリル酸メチル (PMMA)) 微粒子 の表面修飾 ${ }^{5), 6)}$}

まず，多角バレルスパッタリング法による微粒子材料 $(0$ 次元材料)の表面修飾について述べる。图 2 には Pt 修飾し たPMMA 微粒子(粒径: $50 \mu \mathrm{m}$ )を示している ${ }^{5)}$ 。光学顕微 鏡写真(図 $2(\mathrm{I})$ ) より, 修飾前の PMMA 微粒子は白色であ るが, Pt スパッタリング後は金属色を呈している。また, 個々 の微粒子表面には隣接する微粒子からの反射光が映り込むほ ど，光沢のある鏡面になっていることが見て取れる。これら 微粒子の SEM 像(図 2 (II)) から，スパッタリング前後で微 粒子表面の形態には大きな違いは認められない。しかし EPMA 測定（図 2 (III))では，スパッタリングした試料にのみ SEM 像と同じ形状で Pt 元素が一様に検出された。これらの 結果は, 多角バレルスパッタリング法により, PMMA 微粒 子表面は Pt 薄膜 (TEM 観察より, 膜厚約 $50 \mathrm{~nm}$ ) で均一にコー ティングされていることを示している。図2（IV)は他の金属 を修飾した PMMA 微粒子(粒径：15 $\mu \mathrm{m}$ )の写真を示した。 それぞれの試料は，修飾した金属に由来する色合いを呈して いる。また電子顕微鏡観察より, どの試料も $\mathrm{Pt}$ 修飾試料と 同様，種々の金属薄膜で均一にコーティングされていること がわかった ${ }^{6)}$ 。

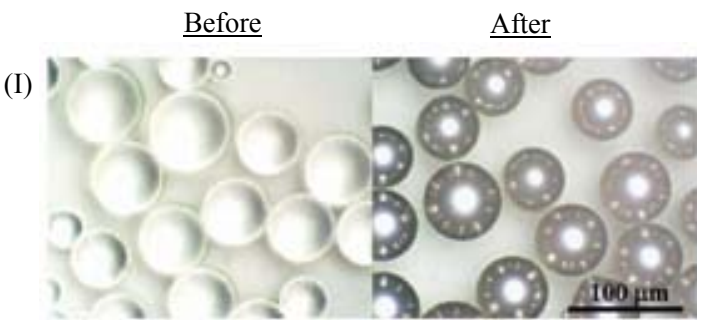

(II)
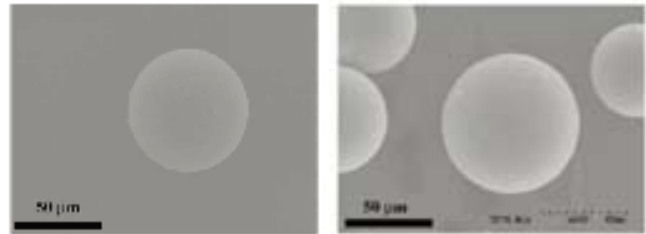

(III)

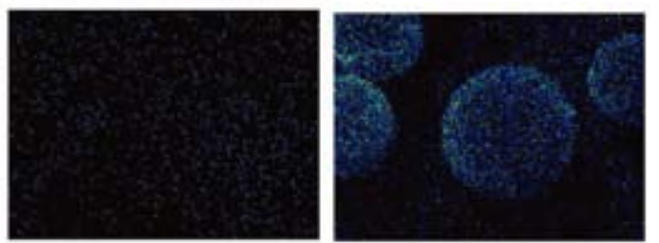

(IV)

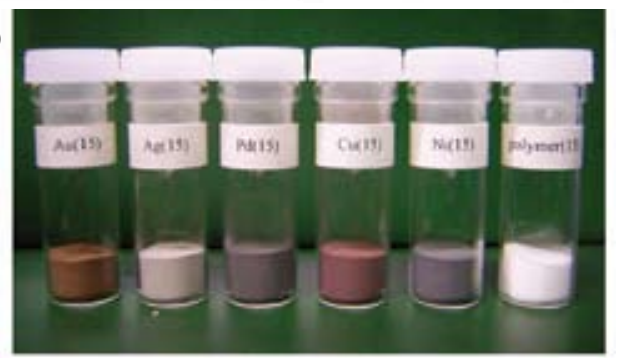

図 2 PMMA 微粒子(粒径 $50 \mu \mathrm{m}$ ) の Pt 修飾前後の ( I ) 光学顕微鏡写真, (II) SEM 像, （III） EPMA マッ ピングと (IV) 各種金属で表面修飾した PMMA 微 粒子(粒径 $15 \mu \mathrm{m}$ )の外観写真

\section{2 イオン性結晶表面の $P t$ 修飾}

多角バレルスパッタリング法はドライプロセスであること から，めっき法では難しい水溶性物質 (例えばイオン性結晶) 表面への修飾も可能である。図 $3(\mathrm{~A})$ に $\mathrm{Pt}$ 修飾 $\mathrm{NaCl}$ 粒子の 光学顕微鏡写真を示す。比較のため, 修飾前の試料写真も併 せて示した。修飾前試料は半透明であるのに対し，修飾後試 料は金属色に変化しており，粒子表面が Pt 薄膜でコーティ ングされていることがわかる。なお，修飾試料の表面に凹凸 が認められるが，これは元の $\mathrm{NaCl}$ 粒子表面に存在する凹凸 が，金属膜の被覆により陰影が強調されたためである。実際 に, Pt コーティングを施した試料を水に入れても沈殿した ままであり，修飾した $\mathrm{Pt}$ 皮膜が極めて緻密な膜であること が示唆された。

\section{3 酸化物修飾 ${ }^{7) \sim 11)}$}

本法は金属以外の修飾物質も使用可能である。例えば，酸 素存在下で反応性スパッタリングにより金属酸化物を修飾で きる7)。図 $3(\mathrm{~B})$ に $\mathrm{SnO}_{2}$ を修飾したアルミフレークの写真 を示した。試料の色は調製時の $\mathrm{RF}$ 出力増加 $(0,195,350$, $490 \mathrm{~W}$ )に従って, アルミフレーク自体の金属色から黄(膜厚： $80 \pm 15 \mathrm{~nm}) \rightarrow$ 赤 $(130 \pm 20 \mathrm{~nm}) \rightarrow$ 青 $(180 \pm 20 \mathrm{~nm})$ と変化し た。これは, $\mathrm{SnO}_{2}$ 膜厚の増加にともなう干渉色の変化に起 因している。また，それぞれの試料で単一の干渉色が認めら れたことは, 個々のアルミフレーク表面に修飾された $\mathrm{SnO}_{2}$ 皮 膜の厚さがほぼ均一なことを示している。紙面の関係上割愛す るが, 他の酸化物 $\left(\mathrm{TiO}_{2}, \mathrm{WO}_{3}\right)^{8), 9}$, 炭化物 $(\mathrm{WC})^{10)}$, 窒化物 $(\mathrm{TiN})$ ${ }^{11)}$ による微粒子表面修飾も可能なことを報告している。

\section{3. カーボンナノチューブ・ナノファイバー (1 次元 $)$ 材料の表面修飾 ${ }^{12}$}

カーボンナノチューブ $(\mathrm{CNT})$ やカーボンナノファイバー $(\mathrm{CNF})$ は, ナノメートルオーダーの繊維径を持つ一次元の炭 素材料であり, 特異な電気伝導性や機械的強度を有すること から，幅広い分野で注目されている。例えば，金属ナノ粒子

(A) Pt-modified rock salts
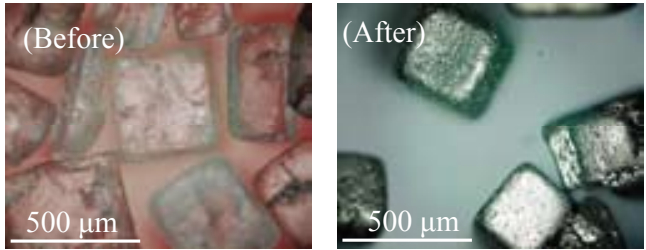

(B) $\mathrm{SnO} 2$-modified $\mathrm{Al}$ flakes

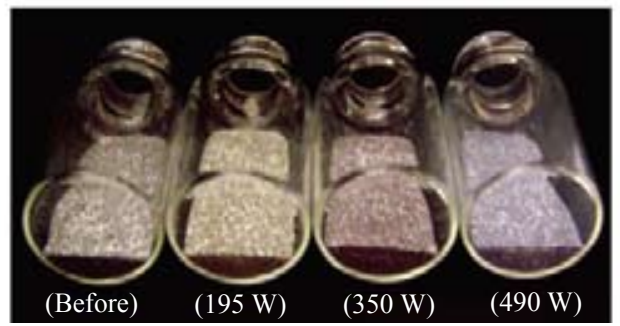

図 3 (A) Pt スパッタリング前後の岩塩表面の光学 顕微鏡写真

(B) $\mathrm{SnO}_{2}$ 修飾アルミフレーク外観写真 
を担持した CNT や CNF は燃料電池用電極触媒やバイオセン サーなどへの応用が検討されている。しかし，通常のウエッ トプロセスを用いた CNT や CNF 表面への金属ナノ粒子担持 には，1）CNT および CNF 表面の前処理が必要，2)金属ナノ 粒子のチューブ内析出が避けられない, などの問題が指摘さ れている。そこで, 多角バレルスパッタリング法を用いて, 未処理の CNT および CNF 表面への金属ナノ粒子修飾を試み た。図 4 (A) には繊維径 $150 \mathrm{~nm}$ (繊維長 : $10 \sim 20 \mu \mu \mathrm{m}$ )の $\mathrm{CNF}$ にPt を担持した試料の TEM 像を示した。黒い点として 見える Ptナノ粒子が全ての CNF 表面に担持されている。図 (A) 中黒枠内を拡大したのが図 4 (B)である。比較のために, 担持前の CNF 表面も図 $4(\mathrm{C})$ に示した。修飾前の CNF 表面 は比較的平坦であるのに対し，修飾後の試料表面には粒径 2 〜 $4 \mathrm{~nm}$ の $\mathrm{Pt}$ ナノ粒子(平均粒径 : $2.2 \mathrm{~nm}$ ) が極めて均一に担 持されていることがわかる。同様な結果はCNT（繊維径： $10 \mathrm{~nm}$, 繊維長 : $5 \sim 15 \mu \mathrm{m})$ でも得られている。次に, TEM の試料台を種々の角度に傾けながら順次測定した像を示す (図 4 (D)，(E))。これは通常の TEM 像 (透過像)では，担持 $\mathrm{Pt}$ ナノ粒子が CNF 外表面と空洞内のどちらに存在するのか を判別できないためである。図 4 (D) には含浸法で調製した 試料の結果を示した。黄枠で示した Pt ナノ粒子 (粒径 $: 8 \mathrm{~nm}$ ) は試料台の角度変化に追随して徐々に図中下側に移動したが, 赤枠中のナノ粒子は全く移動していない。つまり, 赤枠内の 粒子は空洞内に存在していることを示す。Pt 粒子の粒径と個 数から, 含浸試料では全担持 Pt 量の $37 \%$ が空洞内に担持さ れていた。一方, 多角バレルスパッタリング法で作製した試 料(図 4 (E))では，黄枠で示したナノ粒子のように全粒子の 移動が認められた。すなわち，担持したPtナノ粒子は全て $\mathrm{CNF}$ 外表面に均一に担持されていることを示している。

\section{4. ボルト・ナット・ネジ (3 次元) 材料の表面修飾 ${ }^{12)}$}

ここまでは微細な対象物である微粒子や CNT や CNF 材料 の表面修飾について述べてきた。次に通常のめっき対象物で ある $\mathrm{mm} \sim \mathrm{m}$ オーダーの 3 次元材料の表面修飾について示 す。図 5(A)には $\mathrm{Au}$ スパッタリング前後での真鋳製ボルト・ ナット，ポリカーボネート製ネジ，さらにSUS-303 製微小 ネジの外観写真を示す。いずれの材質においても，形状・大
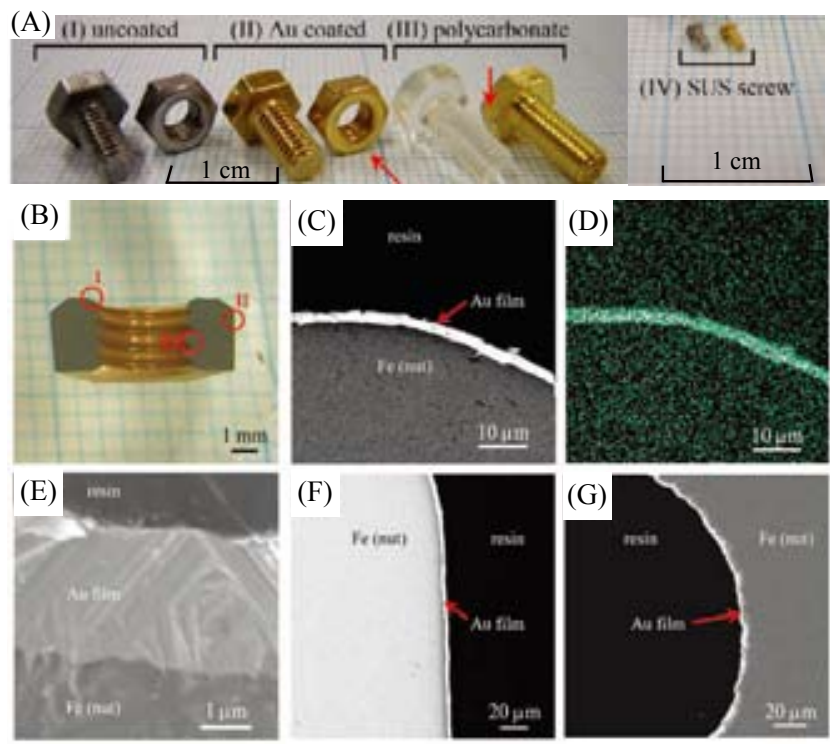

図 5 (A) Au で表面修飾した各種ボルト・ナット・ネジ ( I ， II ： 真鋳製，III：ポリカーボネート製，IV：SUS 製)の外観写真 と真鋳製ナットの断面観察結果

(B) : 断面写真,

(C)，（D）：観察点 I における SEM 像と EPMA マッピング像

(E)：SEM 像 $(\mathrm{C})$ の拡大図

(F)，（G）：観測点II，IIIにおける SEM 像

(A)

(B)

(C)

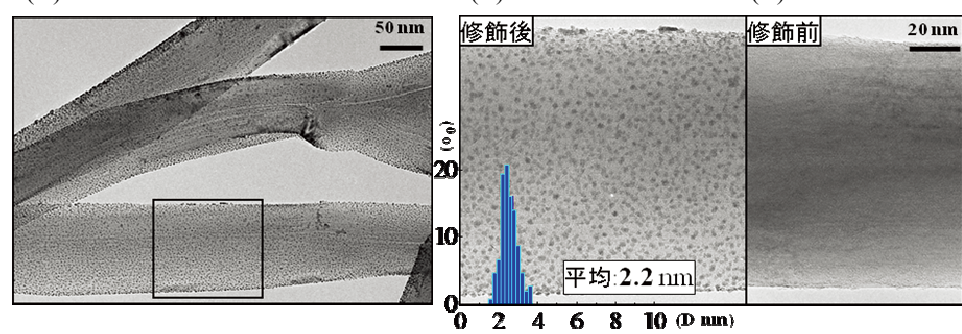

(D)

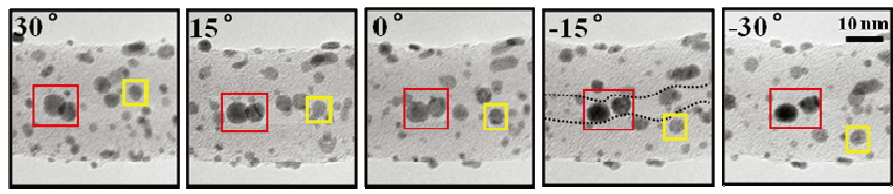

(E)

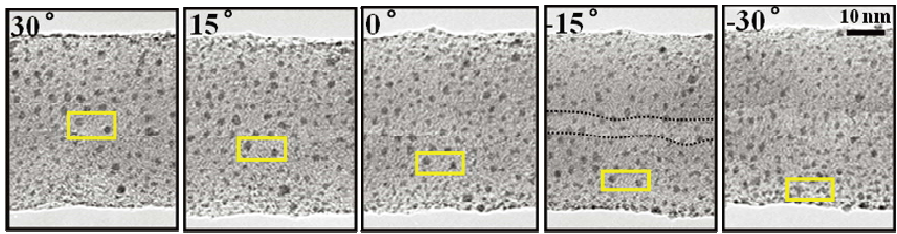

図 4 (A) Pt スパッタリング後の CNF TEM 像, （B）黑枠内の拡大図，（C) スパッタリ ング前の CNF 表面，（D)含浸試料の TEM 像,（E）スパッタリング試料の TEM 像 
きさに関わらず，スパッタリング後の試料は一様に金色を呈 し，グラフ用紙の映り込みも認められる (赤矢印部分) 程, 表 面は平滑であった。このうち, 真鋳製ナットの断面(図 5 (B)) の（I）部を SEM 観察すると，固定用樹脂と真鋳界面に白い帯 のように見える層が観測される(図 $5(\mathrm{C}))$ 。 EPMA マッピン グ像 (図 $5(\mathrm{D}))$ から, この部分は修飾した $\mathrm{Au}$ 皮膜 $(2.7 \pm$ $0.2 \mu \mathrm{m})$ であることがわかる。なお，図 5 (E)に示した修飾界 面の拡大図より，Au はナット表面上に緻密な膜として形成 されており, $\mathrm{Au}$ 皮膜の剥離や亀裂などの欠陮は認められな かった。一方, 図 $5(\mathrm{~F}),(\mathrm{G})$ は, ナットの外表面(測定箇所： 図 5 (B- II )) とネジ凹部(図 5 (B-III )) の SEM 像を示す。これ らの部分においても, 図 $5(\mathrm{C})$ と同等の膜厚を有する $\mathrm{Au}$ 皮膜 が観測された(厚み：外部 $2.9 \pm 0.1 \mu \mathrm{m}$ ，谷部 : $2.8 \pm 0.8 \mu \mathrm{m}$ )。 多角バレルスパッタリング法は指向性の高いスパッタリング 技術を用いているが，ボルト・ナット・ネジのような複雑な 形状を有する 3 次元材料表面でも均一コーティングが可能で あり，「めっき」の代替となるドライプロセスとして有望で あると言える。

\section{5. 多角バレルスパッタリング法の機能性材料への 応用}

ここまで材料表面の物質修飾について記してきたが，ここ からは機能性材料(例として「触媒」)の調製とその特性につ いて述べる。一般に,「触媒」は特異な機能(活性化エネルギー の低減や選択性の向上など)を発現する各種工業・産業にお ける影の立役者である。従来, 不均一触媒は種々のウエット プロセス(広義の「めっき」)を用いて調製されていたため, ブラックボックス的な要素が多く含まれていた。すなわち, 溶媒, 錯体, 添加物などが存在する環境下, これらの物質や イオンが最終生成物に与える影響はほとんど考慮されていな い。また，さまざまな前処理や後処理なる工程(表面処理, 加熱還元, 酸化処理など) も必要である。これでは「デザイ ンされた触媒表面」を構築し, 目的とする化学反応を制御する ことは至難の業である。一方, 多角バレルスパッタリング法は 種々の調製要素を制御しやすいドライプロセスであり，上記問 題を排除した触媒調製が可能である。以下では近年，世界中で 問題視されている地球温暖化現象の主要因とされる二酸化炭素 $\left(\mathrm{CO}_{2}\right)$ の削減に寄与する高性能触媒について述べる。

\section{1 燃料電池用電極触媒の調製 ${ }^{14) \sim 16}$}

燃料電池は, 水素の酸化反応と酸素の還元反応から発電を 行い, 原理的には $\mathrm{CO}_{2}$ を排出しない発電システムである。 このうち，作動温度が低温 $\left(100{ }^{\circ} \mathrm{C}\right.$ 以下 $)$ である固体高分子型 燃料電池 (PEFC) は自動車や家庭用電源として実験的な使用 が始まっている。しかし，本格的な実用化を目指すためには， さらなる耐久性向上やコスト削減が不可欠である。幾つもの 要素技術の革新的なブレークスルーが必要であるが，電極材 料として用いられている Pt や Pt 合金の使用量削減や電極自 体の高性能化もその一つである。著者らは多角バレルスパッ タリング法を用いてカーボン担体上に Pt-Ru 合金を担持した アノード触媒 $(\mathrm{Pt}-\mathrm{Ru} / \mathrm{C}$ ，合金組成 $: \mathrm{Pt}: \mathrm{Ru}=50: 50$ at.\%)を 調製し，その特性を検討した ${ }^{14)}{ }^{15)}$ 。その結果，図 $6(\mathrm{~A})$ に示 すように，本法で調製した試料の Pt-Ru 合金ナノ粒子は，市
販試料より明らかに微細で粒径も均一であった。さらに, 調 製試料に担持された個々のナノ粒子の合金組成は 52.9 : 47.1 at.\% ( \pm 5.3$)$ であり，市販試料の組成(51.0：49.0〜 $89.4: 10.6$ at.\%) に比べ，極めて均一であった。これらの特 性により，調製試料をアノードに用いた場合，発電性能を低 下させることなく金属使用量を普及時の目標レベル（現状の 約 1/10)にまで削減できることを示した ${ }^{14)}$ 。また，調製した 試料の CO 耐性や水素酸化特性も市販試料に比べ優れている ことを明らかにした。なお, 本法により調製した Pt 担持カー ボン $(\mathrm{Pt} / \mathrm{C})$ 電極触媒 ${ }^{15)}$ や直接メタノール燃料電池用電極触媒 16)の電気化学特性についても報告している。

\section{5. $2 \mathrm{CO}_{2}$ メタン化触媒の調製 ${ }^{17)}$}

不均一触媒を用いた $\mathrm{CO}_{2}$ 水素化によるメタン生成反応 $\left(\mathrm{CO}_{2}+4 \mathrm{H}_{2} \rightarrow \mathrm{CH}_{4}+2 \mathrm{H}_{2} \mathrm{O}\right)$ は $\mathrm{CO}_{2}$ 削減に対し有効であるだ けでなく，生成したメタンを燃料として再利用できる利点を 有する。しかし，この触媒反応は通常 $400{ }^{\circ} \mathrm{C}$ 程度の熱を必要 とし(新たな $\mathrm{CO}_{2}$ 発生誘引), 今まで「意味のない反応」と 考えられてきた。しかし最近，多角バレルスパッタリング法 を用いて $\mathrm{TiO}_{2}$ 微粒子上に $\mathrm{Ru}$ ナノ金属を担持した触媒 $(\mathrm{Ru} /$ $\left.\mathrm{TiO}_{2}(\mathrm{~B})\right)$ では室温から $\mathrm{CO}_{2}$ の水素化反応が進行し, 約 $150{ }^{\circ} \mathrm{C}$ で転化率，選択率共に $100 \%$ の触媒活性を示すことを 見出した (図6 (B) 参照)。これは含侵法で調製した従来の $\mathrm{Ru}$ 担持触媒 $\left(\mathrm{Ru} / \mathrm{TiO}_{2}(\mathrm{~W})\right)$ に比べ, $200{ }^{\circ} \mathrm{C}$ 以上低温で反応が 進行することを示している。両者の触媒物性を比較したとこ

(A) $\mathrm{Pt}-\mathrm{Ru} / \mathrm{C}$ samples for PEFC anode catalyst

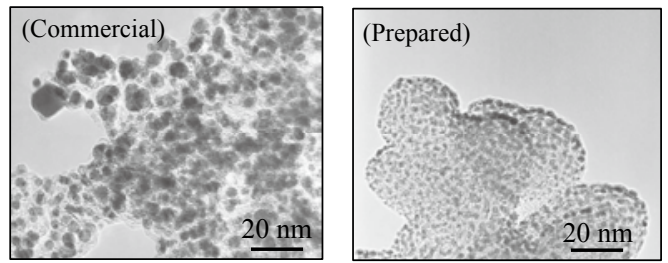

(B) $\mathrm{CO}_{2}$ methanation reaction on $\mathrm{Ru} / \mathrm{TiO}_{2}$ catalysts

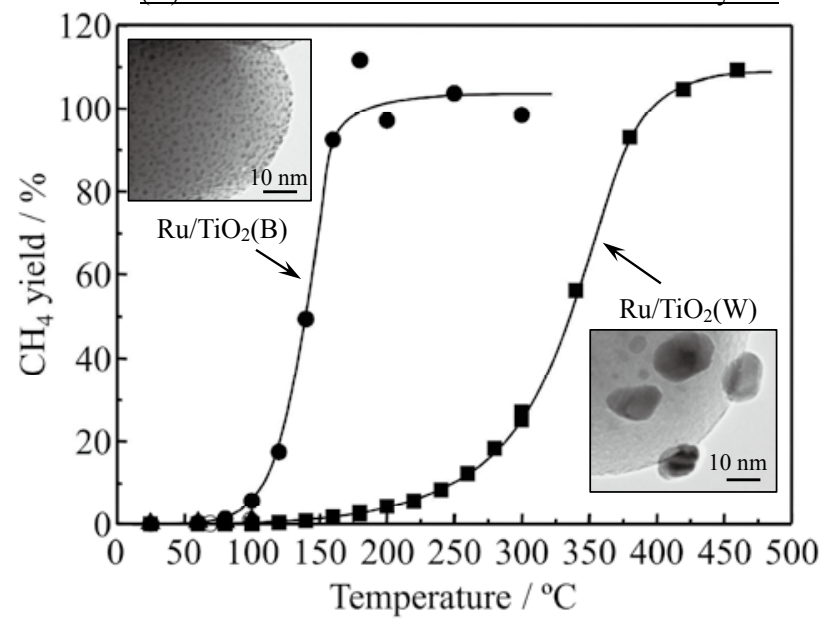

図 6 (A) PEFC アノード Pt-Ru/C 触媒試料の TEM 像(黒点が $\mathrm{Pt}-\mathrm{Ru}$ 合金ナノ粒子)

(B) $\mathrm{Ru} / \mathrm{TiO}_{2}$ 試料を用いた $\mathrm{CO}_{2}$ メタン化反応におけるメ夕 ン収率の温度依存性

多角バレルスパッタリング法調製試料： $\mathrm{Ru} / \mathrm{TiO}_{2}(\mathrm{~B})$ ウエット法調製試料： $\mathrm{Ru} / \mathrm{TiO}_{2}(\mathrm{~W})$

扦入図 : $\mathrm{Ru} / \mathrm{TiO}_{2}(\mathrm{~B})$ と $\mathrm{Ru} / \mathrm{TiO}_{2}(\mathrm{~W})$ の $\mathrm{TEM}$ 像 
ろ, $\mathrm{Ru} / \mathrm{TiO}_{2}(\mathrm{~B})$ では担持された $\mathrm{Ru}$ 粒子の粒径が約 2 $3 \mathrm{~nm}$ であり, かつ粒径分布も単分散系に近いことがわかった。 一方, 焼成・還元処理が必要な $\mathrm{Ru} / \mathrm{TiO}_{2}(\mathrm{~W})$ の $\mathrm{Ru}$ 粒径分布 は $5 \sim 20 \mathrm{~nm}$ であり， $\mathrm{Ru} / \mathrm{TiO}_{2}$ (B) と明らかに異なっていた。 さらに Ru 粒子径と TON 数(表面積を考慮した反応速度), および反応開始温度の詳細な検討から， Ru 粒子径が $6 \mathrm{~nm}$ 以 下になると TON 数が急激に増加し, それにともない反応開 始温度も低下することが明らかとなった。つまり, $\mathrm{Ru} / \mathrm{TiO}_{2}(\mathrm{~B})$ 触媒の高い活性は担持金属の高表面積化に依存しているので はなく, 担持金属粒子のナノ化による特異な物性変化に起因 していることが示唆された。この結果から, $\mathrm{Ru} / \mathrm{TiO}_{2}(\mathrm{~B})$ を用 いた $\mathrm{CO}_{2}$ メタン化反応は $\mathrm{CO}_{2}$ 削減に貢献できる「極めて有 望な反応」であると言える。

\section{6.おわりに}

材料の表面改質や修飾は，あらゆる産業において久かせな い技術である。しかし，めっき技術による材料の表面修飾は， 近年の環境問題への関心の高まりから厳しい制約に縛られ, 難しい状況にある。それにも関わらず，科学技術の進歩や経 済成長にともない, 新しい表面修飾材料の需要や要求が高 まってきている。つまり，めっき代替技術の開発は待ったな しの状況であると言えよう。今回紹介した多角バレルスパッ タリング法は環境に優しいプロセスであり, 性能的にもめっ き法の代替技術と十分成りえることを示した。また，本法に よる表面修飾は新しい機能性ナノ材料の開発に対して大きな 可能性を秘めており，さまざまな分野への新たな展開が期待 できる。最後に, 本法が各産業や科学技術の今後の発展の一 助となれば幸いである。

\section{文献}

1 ) 稲本順一; 表面技術, 57,889 (2006)

2 ）例えば, 星野重夫; 表面技術, 56, 302 (2005). 藤原 裕; 表面技術, 57, 479 (2006). 森 邦夫, 阿部四郎; 表面技術, 59, 299 (2008).

3 ) 金原 粲; スパッタリング現象 基礎と薄膜・コーティング技 術への応用 (東京大学出版, 1984).

4 ) T. Abe, S. Akamaru, K. Watanabe ; J. Alloys Compd., 377, 194 (2004).

5 ) T. Abe, S. Akamaru, K. Watanabe, Y. Honda ; J. Alloys Compd., 402, 227 (2005)

6 ) A. Taguchi, T. Kitami, H. Yamamoto, S. Akamaru, M. Hara, T. Abe ; J. Alloys Compd., 441, 162 (2007).

7 ) T. Abe, S. Higashide, M. Inoue, S. Akamaru; Plasma. Chem. Plasma. Process., 27, 799 (2007).

8 ) S. Akamaru, S. Higashide, M. Hara, T. Abe ; Thin Solid Films, 513, 103 (2006)

9 ) T. Abe, H. Hamatani, S. Higashide, M. Hara, S. Akamaru ; J. Alloys Compd., 441, 157 (2007)

10) S. Akamaru, H. Yamamoto, T. Abe ; Vacuum, 83, 633 (2009).

11) S. Akamaru, Y. Honda, A. Taguchi, T. Abe ; Materials Transactions, 49, 1638 (2008).

12) H. Yamamoto, K. Hirakawa, T. Abe ; Mater. Lett., 62, 2118 (2008).

13) A. Taguchi, T. Kitami, S. Akamaru, T. Abe ; Surf. Coat. Technol., 201, $9512(2007)$.

14) M. Inoue, H. Shingen, T. Kitami, S. Akamaru, A. Taguchi, Y. Kawamoto, A. Tada, K. Ohtawa, K. Ohba, M. Matsuyama, K. Watanabe, I. Tsubone, T. Abe ; J. Phys. Chem. C, 112, 1479 (2008).

15) M. Inoue, S. Akamaru, A. Taguchi, T. Abe ; Vacuum, 83, 658 (2009).

16) K. Hirakawa, M. Inoue, T. Abe ; Electrochim. Acta, 55, 5874 (2010).

17) T. Abe, M. Tanizawa, K. Watanabe, A. Taguchi ; Energy Environ. Sci., 2,315 (2009).

(Received September 26, 2011) 